\title{
Serum Leptin and Skeletal Differences between Obese and Non-Obese Patients with Chronic Obstructive Pulmonary Disease
}

\author{
Marta Koršića Vesna Kušec ${ }^{b}$ \\ ${ }^{a}$ Clinic for Lung Disease, Clinical Hospital Centre Zagreb, Zagreb, Croatia; ${ }^{b}$ Clinical Institute \\ of Laboratory Diagnosis, Clinical Hospital Centre Zagreb, Zagreb, Croatia
}

\section{Key Words}

Body mass - Body mass index - Fat mass - Fat mass index - Lean tissue mass - Lean tissue mass index $\cdot 25-\mathrm{OH}$ vitamin $\mathrm{D} \cdot$ Leptin $\cdot$ Bone mineral density

\begin{abstract}
Objective: Chronic obstructive pulmonary disease (COPD) affects body composition, adipokine secretion, and skeletal integrity. The aim was to determine the association between leptin, body mass (BM) and body composition parameters - fat mass (FM) and fat mass index (FMI), lean tissue mass (LTM), lean tissue mass index (LTMI) and bone mineral density (BMD) in 67 male COPD patients. Methods: BM, body composition and biochemical indicators were measured or calculated using standard methods. Data were analyzed according to groups: non-obese $\left(\mathrm{N}=48\right.$, BMI $\left.21.0-29.9 \mathrm{~kg} / \mathrm{m}^{2}\right)$ and obese $\left(\mathrm{N}=19, \mathrm{BMI} \geq 30.0 \mathrm{~kg} / \mathrm{m}^{2}\right)$. Results: In the non-obese group statistically significant correlations were observed: negative ones of age with most BMD T scores, positive ones of BMI with all T scores, FM, FMI, LTMI and leptin, of FMI with leptin and all T scores, and of LTMI with most T scores. In the obese group also statistically significant correlations were found: positive ones of BMI with FMI, LTM, leptin and T scores (trochanter, total hip); of FMI with leptin; and of leptin with total hip T score. Conclusion: A positive relationship between FMI and BMD was found only in non-obese but not in obese COPD patients. Leptin concentration was associated positively with the total hip T score only in obese COPD patients, suggesting its protective role on the skeleton of obese COPD patients.


Koršića and Kušecb: Serum Leptin and Skeletal Differences between Obese and Non-Obese Patients with Chronic Obstructive Pulmonary Disease

\section{Introduction}

Chronic obstructive pulmonary disease (COPD) is an inflammatory disease of the lungs. However, it is not merely a lung disorder. Cardiovascular, musculoskeletal, metabolic and psychological disorders as well as obesity, which are among the most prevalent comorbidities, make COPD a multicomponent disease. Bone loss is a recognized complication [1-5]. The view that obesity prevents bone loss is widely accepted, but the relationship between body composition and the skeleton is still a matter of conjecture [6-9]. The most frequently mentioned mechanisms through which obesity affects bone include mechanical loading, aromatization of androgens to estrogens, low levels of sex hormone-binding globulin, and the effect of hyperinsulinemia on bone formation [10-12].The role of adipose tissue in the pathogenesis of COPD is still incompletely understood [13]. Adipose tissue is a source of various cytokines such as adipokines which may contribute to systemic inflammation. The excretion of adipokines by adipose tissue may be stimulated by chronic or intermittent hypoxia. It has been proposed that fat mass (FM) and body weight may affect bone mass by means of leptin modulation. In vitro data show that leptin promotes bone formation most likely by influencing stromal marrow cells to promote osteoblast differentiation and inhibit adipocyte differentiation $[14,15]$. Moreover, leptin can reduce osteoclastogenesis by reducing the production of receptor activator nuclear factor $\mathrm{\kappa B}$ and increasing that of osteoprotegerin. It has been suggested that leptin has endocrine and paracrine effects on parathyroid hormone (PTH) and fibroblast growth factor 23 production and that PTH may be one of the signals leading to increased bone mass in obesity [16]. In addition to this local mechanism of action, leptin is also assumed to have a bone catabolic effect via the central hypothalamic relay. Thus, the overall effect of leptin on bone results from the balance between its indirect negative central and its direct positive peripheral effect. In patients with COPD, leptin correlates with BMI and body fat. Vondracek et al. [17] concluded that the effect of adipokines on bone mineral density (BMD) does not seem to be independent of BM. In another study, an inverse association between leptin and BMD has been demonstrated after controlling for body weight, but not after controlling for other bone-related factors [18]. The inconsistent association between adipokines and BMD is probably confounded by body composition, especially fat mass parameters [19].

Leptin is a 16-KD protein product of the $o b$ gene located on chromosome 7 in humans $[20,21]$. White adipose tissue is the main source of leptin, but this hormone is also produced by osteoblasts as well as by the placenta, gastric fundic mucosa, pancreas and lungs [22-28]. Recently, the role of the leptin in the respiratory system has increasingly become a subject of interest [29].

The aim of this study was to determine the association of BMD in 67 male COPD patients with leptin serum concentration and body composition parameters such as FM, fat mass index (FMI), lean tissue mass (LTM), and lean tissue mass index (LTMI).

\section{Subjects and Methods}

Subjects

67 ambulatory male patients with COPD, 46-87 years of age, were recruited from the Outpatient Department of the Clinic for Lung Diseases, Zagreb University Hospital Center, between January 2010 and December 2011. Lung function was determined by spirometry on a MasterScreen Pneumo (Jaeger, Wurzburg, Germany) spirometer which meets American Thoracic Society/European Respiratory Society (ATS/ERS) criteria. Post-bronchodilator forced expiratory volume in $1 \mathrm{~s}$ (FEV1) and forced vital capacity (FVC) were also measured according to the ATS/ERS criteria before and after administration of $400 \mu \mathrm{g}$ of salbutamol. The inclusion criterion was the diagnosis of COPD defined as post-bronchodilator FEV1/FVC $<$ 
Koršića and Kušecb: Serum Leptin and Skeletal Differences between Obese and Non-Obese Patients with Chronic Obstructive Pulmonary Disease

Table 1. Differences in age, anthropometric characteristics, and clinical parameters between obese and nonobese male patients with COPD

\begin{tabular}{|c|c|c|c|}
\hline \multirow[t]{2}{*}{ Characteristics } & \multicolumn{2}{|c|}{ Patients with COPD (median, range) } & \multirow[t]{2}{*}{ p value ${ }^{\dagger}$} \\
\hline & $\begin{array}{l}\text { non-obese }\left(B M I<30 \mathrm{~kg} / \mathrm{m}^{2}\right) \\
(\mathrm{n}=48)\end{array}$ & $\begin{array}{l}\text { obese }\left(B M I \geq 30 \mathrm{~kg} / \mathrm{m}^{2}\right) \\
(\mathrm{n}=19)\end{array}$ & \\
\hline Age, years & $67.0(42.0-87.1)$ & $64.4(51.0-83.0)$ & n.s. \\
\hline $\mathrm{BM}, \mathrm{kg}$ & $78.2(46.4-113.4)$ & $101.1(83.2-125.4)$ & $<0.001$ \\
\hline BMI, $\mathrm{kg} / \mathrm{m}^{2}$ & $26.2(17.7-29.9)$ & $32.7(30.5-41.8)$ & $<0.001$ \\
\hline FM, kg & $29.8(10.7-44.6)$ & $41.4(32.8-45.8)$ & $<0.001$ \\
\hline FMI, $\mathrm{kg} / \mathrm{m}^{2}$ & $7.5(2.0-15.2)$ & $12.8(8.7-23.0)$ & $<0.001$ \\
\hline LTM, kg & $52.9(37.5-66.8)$ & $61.8(43.7-76.1)$ & $<0.001$ \\
\hline LTMI, $\mathrm{kg} / \mathrm{m}^{2}$ & $17.9(14.5-21.2)$ & $18.6(16.0-23.7)$ & $<0.001$ \\
\hline 25-OHD, nmol/l & $35.0(1.0-61.0)$ & $29.5(4.0-64.0)$ & n.s. \\
\hline Leptin, ng/ml & $5.2(0.1-14.8)$ & $16.8(3.5-58.5)$ & $<0.001$ \\
\hline \multicolumn{4}{|l|}{ BMD T-score } \\
\hline L1-L4 & $-0.9(-3.5$ to 3.0$)$ & $0.3(-2.5$ to 2.8$)$ & n.s. \\
\hline Femoral neck & $-1.7(-3.8$ to 0.6$)$ & $-1.0(-2.5$ to 0.7$)$ & 0.018 \\
\hline Trochanter & $-1.1(-3.8$ to 1.5$)$ & $-0.1(-1.5-1.8)$ & 0.008 \\
\hline Total hip & $-1.2(-3.5$ to 1.5$)$ & $-0.2(-2.0$ to 1.4$)$ & 0.004 \\
\hline
\end{tabular}

n.s. $=$ Not significant. ${ }^{\dagger}$ Mann-Whitney test.

$0.70 \%$ and FEV1 $<80 \%$ (on the basis of sex, height, and age). None of the patients had exacerbation of the COPD in the previous 3 months. Patients were not included in the study if they had a history of other significant respiratory diseases, previous lung surgery, significant inflammatory diseases, malignant diseases, or a history of previous malignancy. None of the patients were chronic users of corticosteroid therapy ( $>10 \mathrm{mg}$ prednisolone). Patients receiving therapy for osteoporosis or other skeletal diseases were excluded from the study.

For statistical analysis, patients were divided according to their BMI into two groups: non-obese (BMI of $21-29.9 \mathrm{~kg} / \mathrm{m}^{2}$ ) and obese (BMI $\geq 30 \mathrm{~kg} / \mathrm{m}^{2}$ ).

The study protocol was approved by the Institutional Review Board of the Zagreb University School of Medicine, and all patients signed the informed consent form before inclusion.

Methods

Standing height was measured using a wall-mounted stadiometer. Weight was measured to the nearest $0.1 \mathrm{~kg}$ using a digital floor scale. The BMI was calculated as weight in kg divided by height in meters square $\left(\mathrm{kg} / \mathrm{m}^{2}\right)$. FM $(\mathrm{kg})$, LTM $(\mathrm{kg})$, and BMD $\left(\mathrm{g} / \mathrm{cm}^{2}\right)$ in the lumbar spine (L1-L4), left femoral neck, trochanter and total hip were measured by dual energy X-ray absorptiometry using DXA (Lunar Prodigy Advance, GE Healthcare, Madison, WI, USA). Using the total body measurements, the FMI was calculated by dividing FM $(\mathrm{kg})$ by height squared $\left(\mathrm{m}^{2}\right)$, and the LTMI was calculated by dividing LTM $(\mathrm{kg})$ by height squared $\left(\mathrm{m}^{2}\right)$.

BMD T scores were used in statistical analyses to avoid age effect on bone mass.

Blood sampling was performed during outpatient visits, and serum was separated and frozen until assay. Leptin and 25-hydroxyvitamin D were measured by standard recommended automated methods using commercial reagents (Leptin Elisa, DRG Instruments GmbH, Marburg, Germany; 25-hydroxy Vitamin D EIA, Immunodiagnostic Systems Ltd., Boldon, UK). In men, normal ranges for serum leptin and 25-OH D are $3.84 \pm 1.79 \mathrm{ng} / \mathrm{ml}$ and $>50 \mathrm{nmol} / \mathrm{l}$, respectively.

Data were analyzed by STATISTICA version 10 (Statsoft Inc., Tulsa, OK, USA). The results are shown as medians with ranges. Differences between non-obese and obese group of patients were tested by the MannWhitney test. The linear relationship between two variables was measured by Spearman's correlation coefficient (r). Statistical significance was set at $\mathrm{p}<0.05$. 


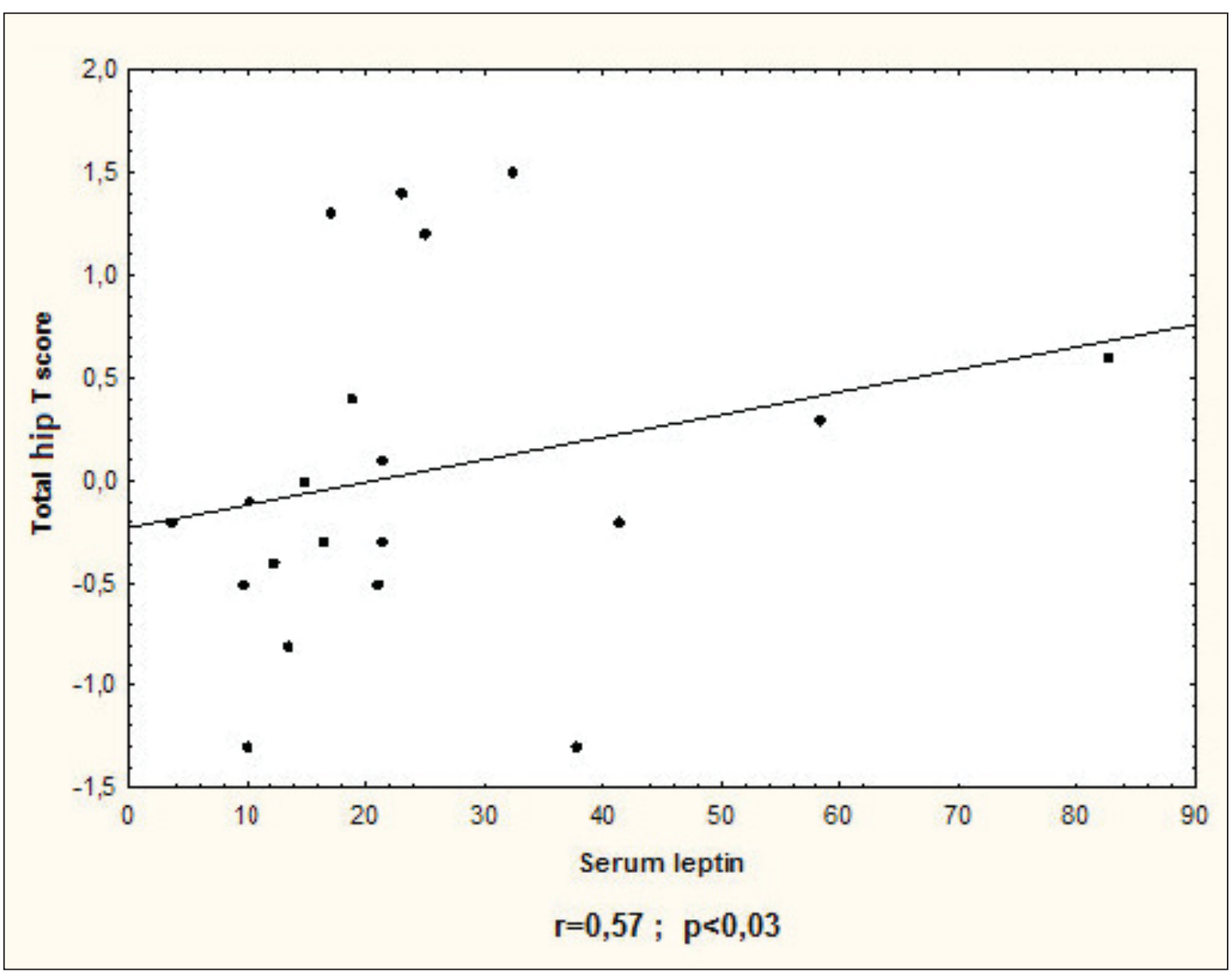

Fig. 1. Correlation between serum leptin concentration $(\mathrm{ng} / \mathrm{ml})$ and total hip $\mathrm{T}$ score in obese patients with chronic obstructive pulmonary disease.

\section{Results}

The essential data are presented in table 1 . One third of patients (19 of 67) were obese, and all 67 patients suffered from vitamin D insufficiency. The non-obese patients were slightly older than the obese ones but without statistical significance. BM, BMI, FM, FMI, LTM, LTMI, and leptin values were significantly lower in the non-obese group. BMD T scores for the femoral neck, trochanter, and total hip were also significantly lower in the non-obese group.

Correlations between the investigated parameters were assessed separately for each group by Spearman's correlation coefficient (r) (tables 2 and 3).

In the non-obese group, there was no correlation of body composition parameters with age (table 2). BM and BMI correlated positively with FM, FMI, LTM, and LTMI as well as with leptin and BMD parameters. FM and FMI correlated positively with leptin and BMD parameters. LTM and LTMI correlated positively with BMD parameters.

In the obese group, BM correlated positively with BMI, LTM, LTMI and BMD T scores for the trochanter and total hip; BMI correlated positively with FMI, LTM, leptin and BMD T scores for trochanter and hip. FM correlated positively with FMI, LTM and LTMI; FMI correlated positively with leptin; LTM correlated positively with LTMI and BMD T scores for the trochanter and total hip. LTMI correlated positively BMD T scores for the trochanter and total hip (table 3, fig. 1). Leptin correlated positively with BMD T score for the total hip. 25-OHD showed no correlation with any parameter. 
Koršića and Kušecb: Serum Leptin and Skeletal Differences between Obese and

Non-Obese Patients with Chronic Obstructive Pulmonary Disease

Table 2. Correlation matrices for age, body traits, 25-OHD and leptin parameters in non-obese male patients with cCOPD, Spearman's $r$ and $p$ values are presented.

\begin{tabular}{|c|c|c|c|c|c|c|c|c|c|c|c|}
\hline \multirow[t]{2}{*}{ Parameters } & \multirow{2}{*}{$\begin{array}{l}\text { Age, } \\
\text { years }\end{array}$} & \multirow{2}{*}{$\begin{array}{l}\mathrm{BM}, \\
\mathrm{kg}\end{array}$} & \multirow{2}{*}{$\begin{array}{l}\mathrm{BMI}, \\
\mathrm{kg} / \mathrm{m}^{2}\end{array}$} & \multirow{2}{*}{$\begin{array}{l}\mathrm{FM} \\
\mathrm{kg}\end{array}$} & \multirow{2}{*}{$\begin{array}{l}\text { FMI, } \\
\mathrm{kg} / \mathrm{m}^{2}\end{array}$} & \multirow{2}{*}{$\begin{array}{l}\text { LTM, } \\
\mathrm{kg}\end{array}$} & \multirow{2}{*}{$\begin{array}{l}\text { LTMI, } \\
\mathrm{kg} / \mathrm{m}^{2}\end{array}$} & \multirow{2}{*}{$\begin{array}{l}\text { 25-OHD, } \\
\mathrm{nmol} / \mathrm{l}\end{array}$} & \multirow{2}{*}{$\begin{array}{l}\text { Leptin, } \\
\mathrm{ng} / \mathrm{ml}\end{array}$} & \multicolumn{2}{|c|}{ BMD Tsc } \\
\hline & & & & & & & & & & L1-L4 & $\begin{array}{l}\text { femoral trochanter } \\
\text { neck }\end{array}$ \\
\hline \multicolumn{12}{|l|}{$\mathrm{BM}, \mathrm{kg}$} \\
\hline $\mathrm{r}$ & 0.31 & - & & & & & & & & & \\
\hline $\mathrm{p}$ value & 0.04 & & & & & & & & & & \\
\hline \multicolumn{12}{|l|}{ BMI, kg/m² } \\
\hline $\mathrm{r}$ & 0.30 & 0.08 & - & & & & & & & & \\
\hline $\mathrm{p}$ value & n.s. & 0.0001 & & & & & & & & & \\
\hline \multicolumn{12}{|l|}{ FM, kg } \\
\hline r & -0.05 & 0.65 & 0.67 & - & & & & & & & \\
\hline$p$ value & n.s. & $<0.0001$ & $<0.0001$ & & & & & & & & \\
\hline \multicolumn{12}{|l|}{$\mathrm{FMI}, \mathrm{kg} / \mathrm{m}^{2}$} \\
\hline $\mathrm{r}$ & -0.09 & 0.76 & 0.81 & 0.93 & - & & & & & & \\
\hline $\mathrm{p}$ value & n.s. & 0.0001 & $<0.0001$ & 0.0001 & & & & & & & \\
\hline \multicolumn{12}{|l|}{ LTM, kg } \\
\hline$r$ & -0.43 & 0.82 & 0.51 & 0.18 & 0.35 & - & & & & & \\
\hline $\mathrm{p}$ value & 0.008 & 0.0001 & 0.0005 & n.s. & 0.02 & & & & & & \\
\hline \multicolumn{12}{|l|}{ LTMI, kg/m² } \\
\hline $\mathrm{r}$ & -0.26 & 0.55 & 0.71 & 0.16 & 0.54 & 0.54 & - & & & & \\
\hline $\mathrm{p}$ value & n.s. & $<0.0001$ & $<0.0001$ & n.s. & $<0.0001$ & 0.002 & & & & & \\
\hline \multicolumn{12}{|c|}{ 25-OHD, nmol/l } \\
\hline$r$ & -0.27 & 0.39 & 0.31 & 0.21 & 0.27 & 0.37 & 0.27 & - & & & \\
\hline $\mathrm{p}$ value & n.s. & 0.03 & n.s. & n.s. & n.s. & n.s. & n.s. & & & & \\
\hline \multicolumn{12}{|l|}{ Leptin, ng/ml } \\
\hline $\mathrm{r}$ & -0.30 & 0.37 & 0.37 & 0.43 & 0.54 & 0.002 & 0.17 & 0.04 & - & & \\
\hline $\mathrm{p}$ value & n.s. & 0.03 & 0.04 & 0.03 & 0.001 & n.s. & n.s. & n.s. & & & \\
\hline
\end{tabular}

\section{BMD TsC}

L1-L4

$\begin{array}{lllllllllllll}\text { r } & -0.14 & 0.41 & 0.39 & 0.45 & 0.35 & 0.37 & 0.18 & 0.14 & 0.08 & - & \\ \text { p value } & \text { n.s. } & 0.003 & 0.005 & 0.003 & 0.01 & 0.01 & \text { n.s. } & \text { n.s. } & \text { n.s. } & & \\ \text { moral neck } & & & & & & & & & & & \\ \text { r } & -0.53 & 0.50 & 0.43 & 0.27 & 0.30 & 0.65 & 0.40 & 0.22 & -0.03 & 0.66 \\ \text { p value } & 0.0002 & 0.0003 & 0.002 & \text { n.s. } & 0.04 & <0.0001 & 0.004 & \text { n.s. } & \text { n.s. } & <0.0001 & \\ \text { ochanter } & & & & & & & & & & & \\ \text { r } & -0.45 & 0.49 & 0.52 & 0.35 & 0.38 & 0.50 & 0.37 & 0.27 & 0.02 & 0.73 & 0.84 & - \\ \text { p value } & 0.003 & 0.0003 & 0.0001 & 0.02 & 0.006 & 0.0006 & 0.008 & \text { n.s. } & \text { n.s. } & <0.0001<0.0001 & \\ \quad \text { tal hip } & & & & & & & & & & & \\ \text { r } & -0.47 & 0.51 & 0.52 & 0.34 & 0.41 & 0.50 & 0.46 & 0.22 & 0.01 & 0.73 & 0.90 & 0.95 \\ \text { p value } & 0.001 & 0.0001 & 0.0001 & 0.03 & 0.004 & <0.0001 & 0.0009 & \text { n.s. } & \text { n.s. } & <0.0001<0.0001<0.0001\end{array}$

$\mathrm{T}$ sc. $=\mathrm{T}$ score; $\mathrm{r}=$ Spearman correlation coefficient; $\mathrm{n} . \mathrm{s} .=$ not significant. 
Koršića and Kušecb: Serum Leptin and Skeletal Differences between Obese and
Non-Obese Patients with Chronic Obstructive Pulmonary Disease

Table 3. Correlation matrices for age, body traits, 25-OHD and leptin parameters in obese male patients with chronic obstructive pulmonary disease (COPD), Spearman's $r$ and $p$ values are presented.

\begin{tabular}{|c|c|c|c|c|c|c|c|c|c|c|c|}
\hline \multirow[t]{2}{*}{ Parameters } & \multirow{2}{*}{$\begin{array}{l}\text { Age, } \\
\text { years }\end{array}$} & \multirow{2}{*}{$\begin{array}{l}\mathrm{BM}, \\
\mathrm{kg}\end{array}$} & \multirow{2}{*}{$\begin{array}{l}\text { BMI, } \\
\mathrm{kg} / \mathrm{m}^{2}\end{array}$} & \multirow{2}{*}{$\begin{array}{l}\mathrm{FM} \\
\mathrm{kg}\end{array}$} & \multirow{2}{*}{$\begin{array}{l}\text { FMI, } \\
\mathrm{kg} / \mathrm{m}^{2}\end{array}$} & \multirow{2}{*}{$\begin{array}{l}\text { LTM, } \\
\text { kg }\end{array}$} & \multirow{2}{*}{$\begin{array}{l}\text { LTMI, } \\
\mathrm{kg} / \mathrm{m}^{2}\end{array}$} & \multirow{2}{*}{$\begin{array}{l}\text { 25-OHD, } \\
\mathrm{nmol} / \mathrm{l}\end{array}$} & \multirow{2}{*}{$\begin{array}{l}\text { Leptin, } \\
\mathrm{ng} / \mathrm{ml}\end{array}$} & \multicolumn{2}{|c|}{ BMD Tsc } \\
\hline & & & & & & & & & & L1-L4 & $\begin{array}{l}\text { femoral trochanter } \\
\text { neck }\end{array}$ \\
\hline \multicolumn{12}{|l|}{$\mathrm{BM}, \mathrm{kg}$} \\
\hline $\mathrm{r}$ & -0.09 & - & & & & & & & & & \\
\hline $\mathrm{p}$ value & n.s. & & & & & & & & & & \\
\hline \multicolumn{12}{|l|}{ BMI, $\mathrm{kg} / \mathrm{m}^{2}$} \\
\hline r & -0.06 & 0.73 & - & & & & & & & & \\
\hline $\mathrm{p}$ value & n.s & $<0.001$ & & & & & & & & & \\
\hline \multicolumn{12}{|l|}{$\mathrm{FM}, \mathrm{kg}$} \\
\hline $\mathrm{r}$ & -0.13 & -0.38 & -0.04 & - & & & & & & & \\
\hline $\mathrm{p}$ value & n.s. & n.s. & n.s. & & & & & & & & \\
\hline \multicolumn{12}{|l|}{ FMI, $\mathrm{kg} / \mathrm{m}^{2}$} \\
\hline $\mathrm{r}$ & 0.07 & 0.44 & 0.58 & 0.54 & - & & & & & & \\
\hline $\mathrm{p}$ value & n.s. & n.s. & $<0.01$ & $<0.02$ & & & & & & & \\
\hline \multicolumn{12}{|l|}{ LTM, kg } \\
\hline $\mathrm{r}$ & 0.07 & 0.87 & 0.67 & -0.66 & 0.11 & - & & & & & \\
\hline $\mathrm{p}$ value & n.s. & $<0.001$ & $<0.002$ & $<0.003$ & n.s. & & & & & & \\
\hline \multicolumn{12}{|l|}{ LTMI, $\mathrm{kg} / \mathrm{m}^{2}$} \\
\hline $\mathrm{r}$ & 0.32 & 0.52 & 0.44 & -0.59 & 0.03 & 0.61 & - & & & & \\
\hline $\mathrm{p}$ value & n.s. & 0.02 & n.s. & $<0.01$ & n.s. & $<0.005$ & & & & & \\
\hline \multicolumn{12}{|c|}{ 25-OHD, nmol/l } \\
\hline $\mathrm{r}$ & -0.17 & 0.09 & -0.05 & -0.47 & -0.44 & 0.16 & 0.25 & - & & & \\
\hline $\mathrm{p}$ value & n.s. & n.s. & n.s. & n.s. & n.s & n.s. & n.s. & & & & \\
\hline \multicolumn{12}{|c|}{ Leptin, ng/ml } \\
\hline $\mathrm{r}$ & -0.21 & 0.45 & 0.75 & 0.20 & 0.62 & 0.28 & 0.08 & 0.04 & - & & \\
\hline $\mathrm{p}$ value & n.s. & n.s. & $<0.002$ & n.s. & $<0.02$ & n.s. & n.s. & n.s. & & & \\
\hline
\end{tabular}

\section{BMD TSC}

L1-L4

\begin{tabular}{|c|c|c|c|c|c|c|c|c|c|c|c|c|}
\hline $\mathrm{r}$ & 0.31 & 0.20 & 0.34 & 0.12 & 0.28 & 0.16 & 0.19 & -0.19 & 0.44 & - & & \\
\hline $\begin{array}{l}\mathrm{p} \text { value } \\
\text { moral neck }\end{array}$ & n.s. & n.s. & n.s. & n.s. & n.s. & n.s. & n.s. & n.s. & n.s. & & & \\
\hline $\mathrm{r}$ & 0.03 & 0.11 & 0.12 & -0.24 & -0.13 & 0.17 & 0.24 & 0.30 & -0.03 & 0.19 & - & \\
\hline $\begin{array}{l}\mathrm{p} \text { value } \\
\text { ochanter }\end{array}$ & n.s. & n.s. & n.s. & n.s. & n.s. & n.s. & n.s. & n.s. & n.s. & n.s. & & \\
\hline $\mathrm{r}$ & 0.27 & 0.57 & 0.55 & -0.14 & -0.32 & 0.53 & 0.47 & 0.06 & 0.41 & 0.74 & 0.35 & - \\
\hline $\begin{array}{l}\text { p value } \\
\text { tal hip }\end{array}$ & n.s. & $<0.01$ & 0.01 & n.s. & n.s. & $<0.02$ & $<0.04$ & n.s. & n.s. & $<0.0003$ & n.s. & \\
\hline$r$ & 0.10 & 0.54 & 0.67 & -0.25 & -0.28 & 0.59 & 0.46 & 0.19 & 0.57 & 0.59 & 0.53 & 0.82 \\
\hline p value & n.s. & $<0.02$ & $<0.002$ & n.s. & n.s. & $<0.01$ & $<0.05$ & n.s. & $<0.03$ & 0.007 & 0.02 & $<0.0001$ \\
\hline
\end{tabular}

$\mathrm{T}$ sc. $=\mathrm{T}$ score; $\mathrm{r}=$ Spearman correlation coefficient; $\mathrm{n} . \mathrm{s}$. = not significant. 
Koršića and Kušecb: Serum Leptin and Skeletal Differences between Obese and Non-Obese Patients with Chronic Obstructive Pulmonary Disease

\section{Discussion}

Associations between leptin and body traits were observed for both non-obese and obese patients with COPD. Serum leptin correlated significantly and positively with BM, FM, BMI, and FMI in non-obese patients. In the obese group, leptin correlated with BMI and FMI, as well as with the BMD T score for the total hip.

Positive correlations of leptin with the BMD T score for the total hip may indicate its protective role on skeletal integrity.

Obesity is characterized by increased circulatory leptin concentrations and central leptin resistance due to reduced brain leptin transport and/or down-regulation of its receptors in the central nervous system [30]. It may be noted that not only leptin but also increased levels of insulin and sex steroids may affect BMD in obese subjects [31-33]. Furthermore, the centrally located FM was found to be associated with lower BMD [34], and excessive visceral fat accumulation was found in patients with advanced COPD [35]. It should be mentioned that Chang et al. [36] observed an inverse relationship between central obesity and osteoporosis in elderly osteoporotic females so that an association of central obesity with lower BMD is controversial. We assume that unopposed, direct leptin activity on the skeleton in our obese patients with COPD can prevail, with the consequent beneficial effect on the skeleton, contributing to better skeletal traits (BMD and T scores). However, this speculation should be regarded with caution due to the relatively small sample size and low statistical power of our cross-sectional study. In non-obese patients with COPD, the correlation between BMI and BMD was greater than in obese COPD patients. The protective effect on BMD has been well documented, but excessive BM also seems to have a negative effect on bone metabolism. Leptin, however, was not associated with BMD in non-obese COPD patients in our study.

Several reports have shown that excessive FM may not protect from osteoporosis and that an increased FM may be associated with low BMD and increased risk of bone fracture [37-40]. In a large cross-sectional study including about 13,000 adult men and women, the percentage of body fat was positively associated with osteopenia and nonvertebral fractures [39].

Reference values for the LTMI and FMI are not available for the Croatian population. Therefore, reference values for white non-Hispanic males accrued by the National Health and Nutrition Examination Study (NHANES) were extrapolated from figures S5 and S1 [41]. The following LTMI data $\left(\mathrm{kg} / \mathrm{m}^{2}\right)$ for the 3rd, 50th and 97th percentile of the representative age groups of 45, 60 and 80 years were as follows: 45 years $-15,20,25.2$; 60 years $-15,20,25.4$; 80 years $-16,19,23$ : The respective FMI percentiles were: 45 years $-3,7,14 ; 60$ years -3.5 , 8, 15.3; 80 years: $4,8,13.9$ [41].

Research findings from studies addressing the association of BM and BMD also suggest that factors other than body weight are involved in the final effects of obesity on bone health. Chao [42] analyzed the relationship between obesity and osteoporosis by taking into account the mechanical loading effect of total BM. Zhao et al. [8] confirmed an inverse relationship between bone mass and FM after controlling for mechanical loading effect due to total body weight. Probably, the positive effect of mechanical loading of increased body weight could not overcome the detrimental effects of obesity or leptin deficiency on bone.

Obesity was found in approximately one third of our patients with COPD. Fransen et al. [13] reported potential links between obesity and COPD. Garcia-Olmos et al. [43] reported that $90 \%$ of patients with COPD visiting family practices (in a part of Madrid) presented with comorbidity, with obesity being the third most prevalent disease after arterial hypertension and disorders of lipid metabolism. Similarly to the observations of Janssens et al. [44-46] and Persson et al. [47], vitamin D insufficiency was found in all our COPD patients. Blood concentrations of 25-hydroxy vitamin D were lower in obese than in non-obese patients, but the 
difference did not reach statistical significance. This is in accordance with reported decreased vitamin D bioavailability in obesity [48].

Our groups of non-obese and obese COPD patients did not differ significantly in age, but they did differ in body mass, FM, LTM and their respective indexes. They were all higher in the obese group. Likewise, BMD T scores on measured skeletal sites were also higher in the obese group (except for lumbar spine L1-L4 which were below statistical significance)

In conclusion, we found a positive relationship between adiposity, expressed as FMI, and bone mineral status in non-obese COPD patients COPD. No such association was observed in obese COPD patients. Furthermore, leptin was not associated with BMD in non-obese patients, but was positively associated with BMD T score for the total hip in obese COPD patients. Assumed associations between BMI, body composition and skeletal traits were found in nonobese, vitamin D-insufficient COPD patients. Preliminary data suggest that leptin could play a protective role for the skeleton, possibly hindering the deleterious contribution of an excessive amount of fat in obese, vitamin D-insufficient COPD patients. Altogether, our study supports the notion that leptin may play a direct protective role on bone metabolism in obese COPD patients.

\section{Acknowledgment}

The authors are grateful to Selma Cvijetić, MD, PhD, for her expert help with statistical analysis and suggestions during the preparation of this manuscript.

\section{Declaration of Authorship}

MK was the principal investigator and VK the co-investigator; both authors participated in the preparation of the manuscript.

\section{Disclosure Statement}

The authors declare that they have no conflict of interest.

\section{References}

1 Biskobing MD: COPD and osteoporosis. Chest 2002;121:609-620.

-2 Jørgensen NR, Schwarz P, Holme I, et al: The prevalence of osteoporotic patients with chronic obstructive pulmonary disease - a cross sectional study. Respir Med 2007;101:177-185.

-3 Vrieze A, de Greef MH, Wijkstra PJ, et al: Low mineral density in COPD patients related to worse lung function, low weight and decrease fat-free mass. Osteoporos Int 2007;18:1197-1202.

4 Wouters EFM, Celis MPM, Breyer MK, et al: Co-morbid manifestation in COPD. Respir Med COPD Update 2007;3: 135-51.

5 Nuti R, Siviero P, Maggi S, et al: Vertebral fractures in patients with chronic obstructive disease: the EOLO study. Osteoporos Int 2009;20:989-998.

-6 Nunez NP, Carpenter CL, Perkins SN, et al: Extreme obesity reduces bone mineral density: complementary evidence from mice and women. Obesity 2007;15:1980-1987.

7 Crepaldi R, Romanoto G, Tonin P, et al: Osteoporosis and body composition. J Endocrinol Invest 2007;30(6 suppl):42-47.

8 Zhao LJ, Liu YY, Liu PY, et al: Relationship of obesity with osteoporosis. J Clin Endocrinol Metab 2007;92:16401646.

9 Oros S, Ianas 0, Vladoiu S, et al: Does obesity protect postmenopausal women against osteoporosis. Acta Endo (Buc) 2012;8:67-76.

10 Frost HM, Ferretti JL, Jee WS: Perspectives: some roles of mechanical usage, muscle strength and the mechanostat in skeletal physiology, disease and research. Calcif Tissue Int 1998;62:1-7.

11 Felson DT, Zhang Y, Hannan MT, et al: Effects of weight and body mass index on bone mineral density in men and women: the Framingham Study. J Bone Miner Res 1993;8:567-573. 
Koršića and Kušecb: Serum Leptin and Skeletal Differences between Obese and

Non-Obese Patients with Chronic Obstructive Pulmonary Disease

$-12$

13

14

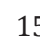

16

16

$$
\text { 1655-1662. }
$$

$>17$

Vondracek SF, Voelkel NF, McDermot MT, et al: The relationship between adipokines, body composition and bone density in men with chronic obstructive pulmonary disease. Int J Chron Obstruct Pulmon Dis 2009;4:267-277.

18 Morberg CM, Tetens I, Black E, et al: Leptin and bone mineral density: a cross-sectional study in obese and non obese men. J Clin Endocrinol Metab 2003;88:5795-5800.

19 Biver E, Salliot C, Combescure C, et al: Influence of adipokines and ghrelin on bone mineral density: a systematic review and meta-analysis. J Clin Endocrinol Metab 2011;96:2703-2713.

20 Zhang Y, Proenca R, Maffei M, et al: Positional cloning of the mouse obese gene and its human homologue. Nature 1994;372:425-432.

21

$>22$ Friedman JM, Halaas JL: Leptin and the regulation of body weight in mammals. Nature 1998;395:763-770.

Reseland JE, Syversen U, Bakke I, et al: Leptin is expressed in and secreted from primary cultures of human osteoblasts and promotes bone mineralization. J Bone Miner Res 2001;16:1426-1433.

$>23$ hormone in humans. Nat Med 1997;3:1029-1033.

Bado A, Levasseur S, Attoub S, et al: The stomach is source of leptin. Nature 1998;394:790-793

Larsson H, Ahren B: Short-term dexamethasone treatment increases plasma leptin independently of changes in insulin sensitivity in healthy women. J Clin Endocrinol Metab 1996, 81:4428-32.

-26 Henson MC, Swan KF, Edwards DE, et al. Leptin receptor expression in fetal lung increases in late gestation in the baboon: a model for human pregnancy. Reproduction 2004;127:87-94.

27 Vernooy JH, Drummen NE, van Suylen RJ, et al: Enhanced pulmonary leptin expression in patients with severe COPD and asymptomatic smokers. Thorax 2009;64:26-32.

-28 Bruno A, Pace E, Chanez P, et al: Leptin and leptin receptor expression in asthma J Allergy Clin Immunol 2009; 124:230-237.

29 Malli F, Papaioannou AI, Gourgoulianis KI, et al: The role of leptin in the respiratory system: an overview. Respir Res 2010;31;11:152.

-30 Ahima RS: Central actions of adipocyte hormone. Trends Endocrinol Metab 2005;16:307-313.

$>31$ Abrahamsen B, Rohold A, Henriksen JE, et al: Correlations between insulin sensitivity and bone mineral density in non-diabetic men. Diabet Med 2000;17:124-129.

-32 Fulzele K, Clemens TL: Novel functions for insulin in bone. Bone 2012;50:452-456.

33 Paller CJ , Shiels MS ,Rohrmann S et al: Relationship of steroid hormones with bone mineral density in nationally representative sample of men. Clin Endocrinol 2009, 70:26-34.

$>34$ Bhupathiraju SN, Dawson-Huges B, Hannan MT, et al: Centrally located body fat is associated with lower bone mineral density (BMD) in older Puerto Rican adults. Am J Clin Nutr 2011;94:1063-1070.

-35 Furutate R, Ishii T, Wakabayashi R, et al: Excessive visceral fat accumulation in advanced chronic obstructive disease. Int J Chron Obstructive Pulmon Dis 2011;6:423-306.

-36 Chang CS, Chang YF, Wang MW, et al: Inverse relationship between central obesity and osteoporosis in osteoporotic drug naïve elderly females: The Tianliao Old People (TOP) study. J Clin Densitom 2013;16:204-211.

$>37$ Goulding A, Taylor RW, Jones IE, et al: Overweight and obese children have low bone mass and area for their weight. Int J Obes Relat Metab Disord 2000;24 :627-632.

38 Blum M, Harris SS, Must A, et al: Leptin, body composition and bone mineral density in premenopausal women. Calcif Tissue Int 2003;73:27-32.

-39 Hsu YH, Venners SA, Terwedow HA, et al: Relation of body composition, fat mass, and serum lipids to osteoporotic fractures and bone mineral density in Chinese men and women. Am J Clin Nutr 2006;83:146-154.

-40 Pollock NK, Laing EM, Baile CA, et al: Is adiposity advantageous for bone strength? A peripheral quantitative computed tomography study in late adolescent females. Am J Clin Nutr 2007;86:1530-1538.

-41 Kelly TL, Wilson KE, Heymsfield SB: Dual energy x ray body composition absorptiometry reference values from NHANES. Plos One 2009;4:e7038.

$\checkmark 42$ Cao JJ: Effects of obesity on bone metabolism. J Orthop Surg Res 2011;6:30.

-43 Garcia-Olmos L, Alberquilla A, Ayala V, et al: Comorbidity in patients with chronic obstructive pulmonary disease in family practice: a cross sectional study. BMC Fam Pract 2013;14:11.

$\checkmark 44$ Janssens W, Lehouck A, Carremans C, et al: Vitamin D beyond bones in chronic obstructive disease: time to act. Am J Respir Crit Care Med 2009;179:630-636.

$>45$ Janssens W, Bouillon R, Claes B, et al: Vitamin D deficiency is highly prevalent in COPD and correlates with variants in the vitamin D-binding gene. Thorax 2010;65:215-220.

$\checkmark 46$ Janssens W, Mathieu C, Boonen S, et al: Vitamin D deficiency and chronic obstructive pulmonary disease: a vicious circle. Vitam Horm 2011;86:379-399.

47 Persson LJ, Aanerud M, Hiemstra PS, et al: Chronic obstructive pulmonary disease is associated with low levels of vitamin D. Plos One 2012;7:e38934.

-48 Wortsman J, Matsuoka LY, Chen TC, et al: Decreased bioavailability of vitamin D in obesity. Am J Clin Nutr 2000; 72:690-693. 